\title{
The poor in the Psalms: A variety of views
}

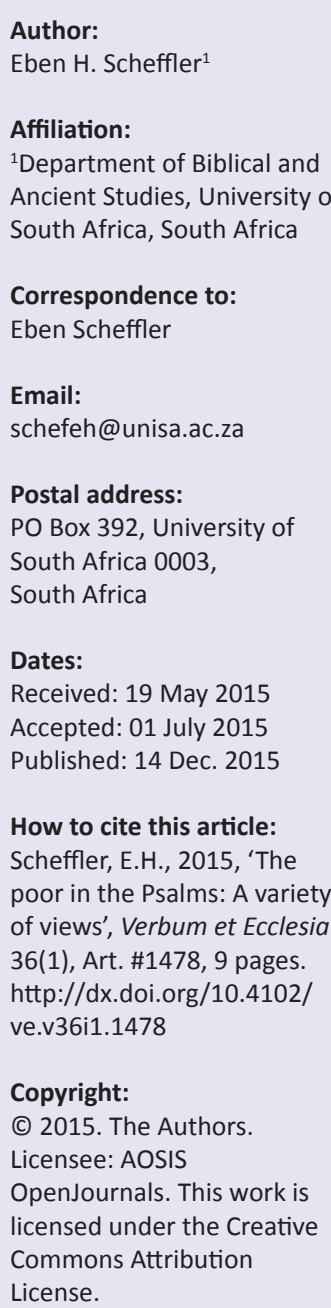

License.
Since the psalms are religious, poetic, existential expressions of life, entailing both extreme joy and intense suffering, it stands to reason that poverty (in its literal sense and otherwise) would receive considerable attention. Focussing on material poverty and challenging the idea of a homogeneous view on poverty (e.g. Armenfrömmigkeit) in the psalms, the diversity of views on poverty in the psalms is explored. Attention is paid to YHWH or God caring for the poor, the (Israelite) king as champion for the poor, the gods (heavenly assembly) (non)caring for the poor, caring for the poor in Zion theology, God as crusher of the poor and mutual human charity. The article concludes with some remarks regarding the possible present-day appropriation of the views in the psalms.

Intradisciplinary and/or interdisciplinary implications: The article challenges the traditional notion on Armenfrömmigkeit in the psalms. This is important for contexts where identifying with the poor are fed by selfish interest and actually feeds exploitation. It also propounds that various views on poverty exist, demanding creative and contextual applicable measures to combat poverty in the present-day world.

\section{Introduction}

The more the world becomes a global village, the more the current problem of poverty in the world constitutes a common problem for humanity. It is therefore not for the sake of being politically correct that this topic should form part of any deliberation on the Psalms. We should relate our work to the problem of poverty because the latter is a problem that affects us all, even though we may attempt to avoid it. In a globalised world, ${ }^{1}$ all are doomed to an existential interest and involvement in the human suffering brought about by (amongst others) poverty. Despite the ideal expressed about 2500 years ago in Deuteronomy 15:4, 11 (cf. Scheffler 2005:97-115) that there should be no poverty in the idealised covenant community, and despite definite measures in the rest of the Hebrew Bible and the New Testament to combat it, ${ }^{2}$ poverty is still rife in the (post) modern world.

However, one should be warned. One must acknowledge that, in the context of academic debate, one deliberates and writes as being non-poor, as part of the elite. One considers people who have no voice themselves, people who are not represented in the debate. For the real poor are infants who cannot yet speak and who die of hunger every day with desperate mothers unable to feed them. Twenty to thirty thousand such people die in the world every day. And it is real. One can just turn on the news and watch pictures on the Ebola-stricken areas of Liberia, but you can also enter any squatter camp in South Africa.

Just as our reflections are reflections by the non-poor, we should keep in mind that, when considering the reflection on poverty in the psalms, we encounter in the psalms a discourse that is also the contemplation of the non-poor authors of the psalms, the ancient Israelite elite. For really poor people only cry out, they do not write poems about poverty. Actually, they can generally per definition not write at all because they are analphabetic. It is possible that there could have been an Armenfrömmigkeit or so-called 'piety of the poor' (see below) in ancient Israel. However, we cannot find that in the written psalms, at least not as far as the extreme poor are concerned. At best, we can find non-poor voices who may attempt to champion for the poor, endeavouring to express desperation on their behalf, or voices pretending to be poor themselves. In our own reflection on poverty in the psalms, we can choose to do it as involved champions for the poor, or we can resort to a detached 'philosophical' stance. In either case, we make a subjective choice, and in either case, we introduce ourselves into the discussion because, as the Talmud says, we do not see the world as it is but as we are.

1.Today it is widely accepted by economists that globalisation has an adverse effect on the poorest of the poor.

2.For a brief overview, see Scheffler (2011b:115-117). See also Scheffler (2012) on Proverbs, (2013b) on the Pentateuch and (2013a:131132) for a brief discussion of the terms used for poverty in the Old and New Testaments. 


\section{Defining poverty}

A wide variety of meanings can be attached to the term 'poverty'. In ancient Israel, people did not reflect on poverty explicitly. This had the effect that poverty could have referred to a wide range of meanings, from the utmost destitution to any kind of misery or suffering, even on a spiritual level. With regard to the latter metaphorical explanation, poverty could (because of God's siding with the poor) even become a virtue to be desired. In Psalm 86:1, for instance, the petitioner prays that God should listen to him or her because she or he is

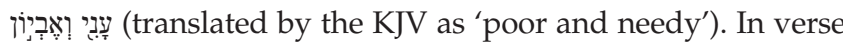
14, the occasion becomes clear: 'the proud rise up against me; a band of ruthless men seeks my life'. The need of the petitioner (his poverty) consists of the threat of the enemy, and the conclusion of the psalm (verse 17) reveals what the satisfying of that need consists of: 'Show me a sign of your favor, so that those who hate me may see it and be put to shame, because you, YHWH, have helped me and comforted me' (Ps 86:17).

It would therefore facilitate our discussion if we attempt to be more precise when we refer to poverty. Jeffery Sachs's (2005a:26-36) distinction in his book The end of poverty between three kinds of poverty and Maslow's (1970) 'hierarchy of human needs' can facilitate the exploration of the theme in the Hebrew Bible.

According to Sachs, a distinction should be drawn between extreme, moderate and relative poverty.

In cases of extreme poverty or absolute poverty ('the poverty that kills'), people have less than $\$ 1$ per day on which to survive. They are chronically hungry and deprived of basic shelter, safe drinking water, sanitation, sufficient clothing, health care and education. About one billion of the world's population (one-seventh) falls into this category. More than eight million people die every year (as said between 20000 to 30000 a day) as a result of extreme poverty. It exists mainly in the developing countries. Asia leads in numbers (approximately 650 million), but Africa has the largest proportion: nearly half its population (approximately 300 million). What makes Africa's situation also qualitatively worse is the fact that, in terms of the population proportion, the situation is worsening in Africa whereas in Asia the situation is improving. The situation of the extreme poor is further aggravated by factors such as HIV or AIDS, drought, isolation and civil wars (Sachs 2005b:26-36).

Moderate poverty, where people live on between $\$ 1$ and $\$ 2$ a day and their needs are barely met, forms Sachs's second category. A further one billion plus people fall into the category of the moderate poor. This means that more than a third of the world's seven billion people can be are regarded as poor, having less than two dollars to live on each day.

Sachs also distinguishes a third category, based on a household income below a given proportion of the national average. People in relative poverty lack things that the middle class takes for granted. In view of the first two categories, it is an open question whether these people, whose poverty exist only in their not being affluent enough to fulfil their own wishes, should be labelled as poor at all. In view of the suffering of the really destitute (those who can die any day), using the term poor for this category may even amount to irreverence, not to mention notions to 'spiritualise' the concept of poverty.

The psychologist Abraham Maslow (1970) distinguished between five categories of human needs which functions in a hierarchical relationship. In other words, the most basic needs should be fulfilled first before the needs of a next level become a human preoccupation (see the discussion in Hjelle \& Ziegler 1976:249-286).

The most basic need is that physical survival, namely to have the minimum water to drink and food to eat each day in order not to die. This level of need correlates with Sachs's notion of absolute or extreme poverty and surely was not the need of the supplicant of Psalm 86:1 who called him or herself poor in the face of the threat of the enemy.

Maslow then continues to discuss four further higher-order needs, namely those for security and shelter, sexual needs (to love and be loved), success in society and self-fulfilment. These I only mention in order to put the notion of desperate physical poverty into relief, but to my mind, they fall within the scope of our reflection on poverty in the psalms to a limited extend only.

Distinguishing Maslow's needs helps us to explain why the eradication of extreme poverty is so important because basic survival is a presupposition for the satisfaction of other higher-order needs. The theory also explains why higher-order needs are often (to my mind wrongfully) referred to as poverty although material destitution is not at stake. ${ }^{3}$

\section{Approaching the theme of poverty in the Psalter}

There are various ways in which one could approach the question of poverty in the Psalms, one being analysing the Hebrew terms used for poverty (dal, rasj, ani/anaw and ebjon) and tracing their occurrences, references, meanings and connotations within the different contexts in which they are employed. Although I shall refer to these terms, such an approach would be too voluminous for my present purpose which is to look for the different and often divergent views expressed in the psalms as far as poverty is concerned in view of the possible value that these views might or might not have for the present-day world. I shall therefore rather follow the route of making general statements that summarise the views in a synthetic fashion to provide us with an overview of the variety of stances that can be

3.For a more detailed discussion of Maslow's theory in the context of poverty in the Bible, see Scheffler (2013a:134-135) 
detected in the Psalms. Table 1 provides the instances where the use of the standard terms occur, instances where the concept is present but the terms absent, as well as instances that refer to material care or prosperity.

The Hebrew Bible often refers to poverty in its most basic form (material destitution), but if one compares it with other issues, references are fairly few and far between. This may be because the Bible was not written by extremely poor people but by the elite. The poorest of the poor were so concerned to find food to eat and to survive that even distanced 'introspective' religious reflection (not to mention writing) on their situation was not possible. However, the fact that the Bible was written by the elite gives significance to the fact that positive references are made to the poor. The tradition of their past existence in poverty (being slaves in Egypt) always remained a prominent part of Israel's collective memory (cf. the reminder in the Decalogue, Ex 20:1; Dt 5:6) and most probably constitutes at least one reason why the plight of the poor received positive attention in the Pentateuch, the Prophets and the Psalms.

Something about the history of the poor in ancient Israel also needs be said. It seems that extreme poverty did not constitute a major problem in Israel's earliest history after the settlement in the land. In fact, the archaeological record of the early Iron Age shows that basic survival strategies were in place that met the most basic needs for food and shelter. In this connection, one can refer to:

1. the numerous water cisterns that were dug in the highland mountains to catch up rain and preserve rain water in great quantities

2. terraces with excellent draining that were built along the hills using the available stones and filling them with fertile soil to grow crops

3. basic houses that were built of sundried mud bricks and mud-plastered roofs made of reeds

4. the growing and cultivation of olive trees

5. the breeding of domesticated animals, especially goats that could survive in mountainous regions and were adapted to a semi-nomadic mode of human existence.

Evidently, this was a form of subsistence farming and peasant life which did not ensure affluence, but it did counter extreme poverty. ${ }^{4}$

With the development of a market economy, probably during the time of Ahab in the 9th century BCE with his Phoenician connections, wealth was produced on a large scale, and a rich class who could trade their surpluses developed. Ironically, people who could not succeed in this system had to get rid of their land (either being forced by immediate economic need or by political force), and a poor class started to develop. The story of Naboth (1 Ki 21) and his vineyard can be regarded as

4.For an elaborate discussion of these issues, see Scheepers (2012:23-41).
TABLE 1: Index of the use of the standard (and other) terms for poverty in the psalms.

\begin{tabular}{|c|c|}
\hline Terms used for poverty in the psalms & References in the psalms \\
\hline $\begin{array}{l}\text { ע̦ ani poor, afflicted, lowly ( } 75 \mathrm{x} \text { in OT, } \\
27 \mathrm{x} \text { in Ps) } \\
\text { anaw poor, humble, weak ( } 20 \mathrm{x} \text { in OT, } \\
11 \mathrm{x} \text { in Ps) }\end{array}$ & $\begin{array}{l}\text { ani } 9: 19 ; 10: 2,9 ; 12: 6 ; 14: 6 ; 18: 28 \\
22: 25 ; 25: 16 ; 34: 7 ; 35: 10 ; 37: 14 ; \\
40: 18 ; 68: 11 ; 69: 30 ; 70: 6 ; 72: 2,4 \\
12 ; 74: 19,21 ; 82: 3 ; 86: 1 ; 88: 16 ; \\
109: 16,22 ; 140: 13 \\
\text { anaw 9:13;10:12, } 17 ; 22: 27 ; 25: 9 \\
34: 3 ; 37: 11 ; 69: 33 ; 76: 10 ; 147: 6 ; \\
149: 4\end{array}$ \\
\hline $\begin{array}{l}\text { אָרִיוֹן ebyon needy, poor, oppressed } \\
\text { (61x in OT, 23x in Ps) }\end{array}$ & $\begin{array}{l}9: 19 ; 12: 6 ; 35: 10 ; 37: 14 ; 40: 18 \\
49: 3 ; 69: 34 ; 70: 6 ; 72: 4,12,13(2 \mathrm{x}) \\
74: 21 ; 82: 4 ; 86: 1 ; 107: 41 ; 109: 16 \\
22,31 ; 112: 9 ; 113: 7 ; 132: 15 ; 140: 13\end{array}$ \\
\hline $\begin{array}{l}\text { t] dal low, poor, helpless (48x in OT, } \\
5 \mathrm{x} \text { in Ps) }\end{array}$ & $41: 2 ; 72: 13 ; 82: 3,4 ; 113: 7$ \\
\hline רש, rash poor (21x in OT, 1x in Ps) & $82: 3$ \\
\hline $\begin{array}{l}\text { Motif without term: } \\
\text { (e.g. helpless, stranger, widow, orphan, } \\
\text { misery, oppressed, the hungry) } \\
\text { Material care or prosperity }\end{array}$ & $\begin{array}{l}9: 9-10 ; 10: 8,10,14,18 ; 23: 1 ; 24 ; \\
68: 6 ; 72 ; 74: 21 ; 78: 63-64 ; 94: 6 ; \\
103: 6 ; 107: 5-9,36,41 ; 109: 6-19 ; \\
119: 50,92,121 ; 145: 14-16 ; \\
146: 7-9 ; 147: 3 \\
4: 8 ; 17: 14 ; 23: 5 ; 34: 11 ; 41: 2 ; \\
62: 11 ; 68: 7 ; 72: 15-17 ; 88: 10,16 ; \\
92: 11-14 ; 107: 5-6,9-1035-38,41 ; \\
128 ; 132: 15-17 ; 145: 14-16\end{array}$ \\
\hline
\end{tabular}

a narrative reflecting this situation. To overcome starvation, people had to sell themselves as slaves, and the gap between rich and poor also grew because of a slave trade that started to develop. ${ }^{5}$

Like any war, the fall of Samaria in 721 BCE and Jerusalem in 586 BCE also caused poverty to increase, and many of the pronouncements on poverty in the Psalms can probably be interpreted within these contexts, addressing the situation.

\section{Poverty in the psalms}

\section{A note on Israelite history and the Mosaic law in relation to the psalms}

About 15 of the psalms (e.g. 44, 47, 60, 68, 77, 78, 80, 81, $99,105,106,108,114,135,136)$ reflect on the history of Israel, and about 12 wisdom psalms $(1,32,34,37,49,73$, $112,119,127,128,133,139)$ reflect on the prescriptions of the law or Torah (not necessarily the final Pentateuch). Many other psalms address the issue of poverty. One can therefore assume that the psalmists stood in the tradition of the Mosaic law that prescribed definite measures in ancient Israelite society, not merely to care for the poor but to combat poverty (see Scheffler 2013b). The view of the past in terms of the exodus or liberation from Egypt (Ex 1-15), the interpretation of experienced poverty in the desert as a testing to keep the Israelites free from apostasy (Dt 8), the idea of family solidarity (Dt 15) and Yahweh's holiness and compassion (Lev 17-25) functioned as motivating factors that would ensure the implementation of the anti-poverty prescriptions. In the reality of Israel's subsequent history, the measures of course had only some of the desired effect, but their general ideology was kept alive in the psalms.

5.For an insightful discussion of these circumstances during the time of Ahab, see Deist (1987:72-84). 


\section{Who are the poor in the Psalms?}

Poverty is referred to in about a third (50) of the psalms (cf. Table 1), which makes a detailed discussion almost virtually impossible. There is also reasonable consensus that the terms usually used for 'poor' in the Hebrew Bible (ani/anaw, ebyon, dal and rash) usually refer to 'the poor' as those in society who are materially destitute, who do not have the basic means for survival and who are so extremely poor that they can die any day. ${ }^{6}$

However, in the Psalms, the matter becomes more complex. Since 1892, when Rahlfs wrote his 'Ani und 'Anaw in den Psalmen in 1892 (quoted in Kraus 1979:188-189), there has been a debate on whether the poor in the Psalms refer to a specific group or party in ancient Israel whose voice we hear in the psalms. That there is reference to the poor in a third of the psalms makes such a view quite attractive.

Since Mowinckel's work ([1921-1924] 1961, quoted in Kraus 1979:189), which refers to the poor in the psalms as the 'Opfer ihrer Feinde', the view of the poor as a specific party has no longer been tenable. Nevertheless the 'romantic' idea of the Psalter as containing the voice of the poor as victims (referred to in German as Armenfrömmigkeit) is still with us, especially amongst those who want to take the plight of the poor in our contemporary world to heart. ${ }^{7}$

If one investigates the biblical material, especially the psalms, one should be honest and not make the text say what it does not. As in the introduction above, I therefore emphasise again that, although positive views to the benefit of the poor may be expressed, the psalms in no way reflects the voice of really poor people who are materially destitute. It would have been pleasing if it were so, but any attempt to declare it so equals the wish of some feminists who desire a female voice in the patriarchal Hebrew Bible and then ascribes female authorship to some biblical books (e.g. Ruth and Song of Songs).

I repeat the simple argument that justifies this statement. The psalms were written by people who could write, and really poor people (in ancient Israel even more than today) could not read or write. They were analphabetic. This basic insight is often ignored by well-meaning scholars or interested groups who want the poor to have a voice in the Bible, who want to hear them speaking in the psalms. These scholars are not confined to social-minority circles but include those from a wealthy background who want to engage in the plight of the poor. Also, the positive views expressed to the benefit of the poor in the psalms also do not represent the 'voice of the poor'. They are elitist voices (of the writing class) that took the plight of the poor to heart as I hope also to do in this contribution.

6 . For a brief discussion of these terms and their "literal" and 'metaphorical" usage in the Hebrew Bible with emphasis on the Psalms, see Groenewald (2003:147-153) and Scheffler (2013b:131-132)

7.According to Groenewald (2003:149) 'Armenfrömmigkeit' (which he translates as 'piety of the poor') manifests itself in the redaction of the Psalter thereby becoming a 'theology of the poor'. To my mind, this view is no more tenable (for the reasons given)
To do justice to the concept of poverty in the psalms, we should realise that the concept functions in different ways in the psalms. The attempt, amongst others by Kraus (1979:189193), to bring under one umbrella all these views and functions of the concept seems to be uncalled for. According to Kraus (1979:188-193), the poor in the psalms are those who are materially poor, on the one hand, but who are also in need of justice to be done to them by God, on the other hand. Although this indeed covers a wide spectrum, to my mind, Kraus's comments do not reflect the kaleidoscopic variety of the functions of the concept of 'poor' in the psalms.

In the Psalter, a concern for the fate of the poor is expressed in various ways in the third person, and there are psalms in which the petitioners refer to themselves as 'poor and

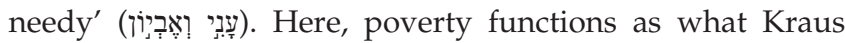
calls Selbstbezeichnung (self-identification). This variety of views now demands our attention, starting with those views expressed about the poor in the third person (cf. Lohfink 1994).

\section{YHWH, God (as king) caring for the poor}

That $Y H W H$ cares for the poor in terms of justice being done to them is expressed in Psalm 9, the first psalm that deals with poverty. Interestingly enough, despite the fact that concern about the poor abounds in Psalm 9 and other psalms, the Western scholars who categorised the psalms according to genres never thought about making poverty a criterion. Would African interpreters do the same?

Nevertheless, in Psalm 9, YHWH is depicted as a refuge for

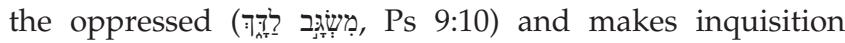

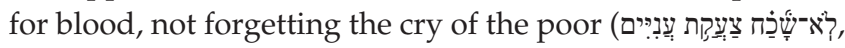
Ps 9:12). A repetition of the same motif occurs in verse 19: 'For the needy shall not always be forgotten, nor the hope of the poor be in vain.'

In his caring for the poor, YHWH himself assumes the role of king. In Psalm 10 (in Catholic Bibles regarded together with Psalm 9 as one psalm ${ }^{8}$ ), the poor's miserable fate is repeatedly ascribed to the actions of wicked men (the poor are therefore innocent, cf. verse 2,9 ):

The poor man is devoured by the pride of the wicked: he is caught in the schemes that others have made. (v. 2)

In Psalm 10:9, the catching metaphor of a lion seizing his prey expresses the same motif:

He lurks in hiding like a lion in his liar;

he lurks in hiding to seize the poor;

he seizes the poor man and drags him away.

In Psalm 10:12, the petitioner calls on YHWH to lift up

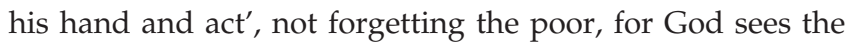
'trouble and sorrow', being 'helper of the orphan' (v. 14). Psalm 10:16-18 states that 'YHWH is king forever and ever ...', and he is addressed as the one who will 'hear the prayer

8.This is highly likely in view of the acrostic feature that links Psalms 9-10 together as well as YHWH's care for the needy that are found in both psalms. 
TABLE 2: The poor in Psalm 146.

\begin{tabular}{|c|c|}
\hline Ps 146:7-9 (MT) & Ps $146: 7-9$ (NRSV) \\
\hline 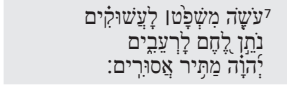 & $\begin{array}{l}{ }^{7} \text { (YHWH) executes justice for the oppressed; } \\
\text { gives food to the hungry. YHWH sets the } \\
\text { prisoners free; }\end{array}$ \\
\hline 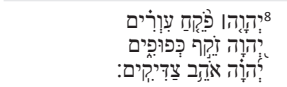 & $\begin{array}{l}{ }^{8} \text { YHWH opens the eyes of the blind. YHWH lifts } \\
\text { up those who are bowed down; YHWH loves the } \\
\text { righteous. }\end{array}$ \\
\hline 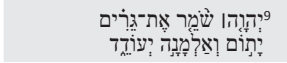 & $\begin{array}{l}{ }^{9} \text { YHWH watches over the strangers; he upholds } \\
\text { the orphan and the widow, }\end{array}$ \\
\hline 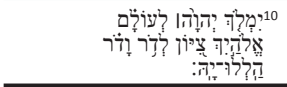 & $\begin{array}{l}\text { YHWH will reign forever, your God, O Zion, for all } \\
\text { generations. Praise the LORD! }\end{array}$ \\
\hline
\end{tabular}

of the poor', who will 'strengthen their heart', doing 'justice for the orphan and the oppressed'. Numerous psalms convey a similar idea of God as king who with compassion does justice to the poor (Pss 103:6; 140:13; 145:7), granting them salvation (Pss 12:6; 35:10; 76:10), hearing them (Pss 34:7; 69:34), being father to the orphan and defending the widow (Pss 68:6; 145:9) and uplifting and supporting the lowly (Pss 113:7; 145:14;145:8).

Worthy of special mention is Psalm 146, a praise song, with the reason for praise accentuated in verses 7-9 (see Table 2).

Various categories of poor people are cared for: the oppressed, the hungry, the blind, those bowed down, and the stranger, the widow and the orphan (the latter three being prominently championed for in Deuteronomic theology, cf Dt 24:14-16 ; Scheffler 2013b:8). Interestingly, none of the classic terms for poverty (ani/anaw, ebyon, dal or rash) is used in Psalm 146, but the concept is unmistakably expressed. ${ }^{10}$

\section{The (Israelite) king caring for the poor}

The second view encountered in the psalms is that the king should care for the poor. As in the wider ancient Near-Eastern world (Kraus 1972:496-497), the motif that the king should care for the poor is poetically and with emphasis expressed in Psalm 72 (dated by Hossfeld \& Zenger [2002:412] to the 7th century $\left.B C E^{11}\right)$. I quote verses $2-4$ and $11-14$ (see Table 3 ).

In what Kraus (1972:493) called a 'Gebet um die heilvolle Herrschaft des Königs' [a prayer for the beneficial rule of the king], the king's care for the poor is based on the justice of God (v. 1). The command to judge the poor fairly resonates with the demands for even-handed justice in the Covenant and Holiness Codes (Ex 23:2-3, 6; Lev 19:15, cf. above). It is wished that the king should be rich and exulted amongst the nations. Ironically, this exultation should not be based on

9.The demand for even-handed justice for the rich (Ex 23:2-3) and the poor (Ex 23:6) is probably rendered in Deuteronomy 24:17, focusing on the stranger, widow (whose garment may not be taken as a pledge) and orphan. The measure is motivated by reference to Israelite slavery in Egypt and the Exodus.

10.On a personal note: I recall the popularity of singing Psalm 146 in its rhymed version as an opening hymn for services of the Dutch Reformed church of which am a member ('Prys die Heer met bly galme, $\mathrm{O}$ my siel daar is ryke stof'). However, the strophes referring to poverty, the widows and the orphans were (because of the custom of selection) almost never sung. In fact, the one on the strangers, widows and have never heard a sermon on this psalm ploete (2001) in the present 'Liedboek'. it is just because the already-mentioned Talmudic adage is true: We see the world as we are.

11.So dated because of its dialogue with Neo-Assyrian and Egyptian Kingship ideology which is taken up and criticised (cf. also Gunkel 1933:160-164).
TABLE 3: The king caring for the poor in Ps 72.

\begin{tabular}{|c|c|}
\hline Ps 72:2-4; 11-14 (MT) & Ps 72:2-4; 11-14 (NRSV) \\
\hline 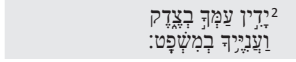 & $\begin{array}{l}{ }^{2} \text { May he judge your people with righteousness, } \\
\text { and your poor with justice. }\end{array}$ \\
\hline 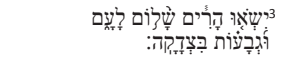 & $\begin{array}{l}{ }^{3} \text { May the mountains yield prosperity for the } \\
\text { people, and the hills, in righteousness. }\end{array}$ \\
\hline 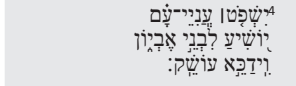 & $\begin{array}{l}{ }^{4} \text { May he defend the cause of the poor of the } \\
\text { people, give deliverance to (the childrent of) } \\
\text { the needy, and crush the oppressor. }\end{array}$ \\
\hline 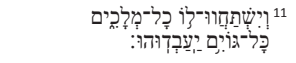 & $\begin{array}{l}{ }^{11} \text { May all kings fall down before him, } \\
\text { all nations give him service. }\end{array}$ \\
\hline 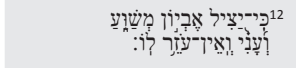 & $\begin{array}{l}{ }^{12} \text { For he delivers the needy when they call, } \\
\text { the poor and those who have no helper. }\end{array}$ \\
\hline 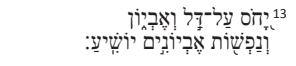 & $\begin{array}{l}{ }^{13} \mathrm{He} \text { has pity on the weak and the needy, } \\
\text { and saves the lives of the needy. }\end{array}$ \\
\hline 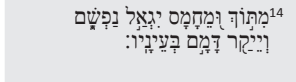 & $\begin{array}{l}{ }^{14} \text { From oppression and violence he redeems } \\
\text { their life; } \\
\text { and precious is their blood in his sight. }\end{array}$ \\
\hline
\end{tabular}

violence but on justice for the poor. ${ }^{12}$ This view on kingship based on compassion for the weak (see v. 13) and on the king being a saviour is unique ${ }^{13}$ and not even present in the other nine royal psalms (Pss 2, 18, 20, 21, 45, 47, 101, 110, 132, 144, cf. however Ps 45:5 where the king 'ride on in triumph for the cause of truth and goodness and justice' but with a violent overtone). In fact, it is noteworthy that the positive acclaim of the king in most of the royal psalms concerns the latter's success in military operations (a possible exception being Ps 101, making Ps 72 even more special). Terms used for poverty in Psalm 72 are ani, ebjon, dal and en ozer lo (the latter rather an expression, 'those with no helper, the helpless'). That justice should be done to the poor is prescribed in the Torah (e.g. Ex 23:2-3, 6; Dt 27:17), and in Psalm 72 the responsibility of the king in this regard is spelt out. Through the king, the God of justice and compassion cares for the poor. He is, in Kraus's (1972:488) terms, God's 'verlängerte Arm' [extended arm] and according to Hossfeld and Zenger (2002:416) 'letzlich nur Mittler/Medium des eigentlichen Königs JHWH'.

This view of kingship can be correlated with the rules for kingship in Deuteronomy 17:14-20, prescribing that the king should not 'increase his gold and silver excessively' (Dt 17:17). This is immediately followed by the instruction to read a copy of the law every day and to observe its precepts (which includes caring for the poor, Dt 17:19, cf. Scheffler 2007:129, 136). It also connects with the prophetic social criticism of the prophets of the 8th and 7th centuries BCE (Hossfeld \& Zenger 2002:413). Nehemiah 5 (especially verses

12.Cf Weiser (1966:343): "Denn in v. 12-15 ist die Machtentfaltung des Königs begründet mit der Gerechtigkeit und dem Mitleid für die Schwachen, die er aus dem Druck der Gewalt erlösen soll'. This is in contrast to Ps 2:9 and 110:5-6, but more in accordance with Is 49:23; Mi 7:14-17 and Is 60:9-11.'

13.It is different from views in Egypt and Mesopotamia where kingship was based on military power and the subjugation of the enemy (Hossfeld \& Zenger 2002:416, cf. also Houston 1999:342-364). 


\begin{tabular}{|c|c|}
\hline Ps 82 (MT) & Ps 82 (NRSV) \\
\hline 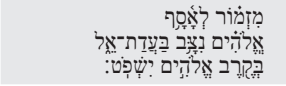 & $\begin{array}{l}\text { A Psalm of Asaph. } \\
\text { God has taken his place in the divine council; } \\
\text { in the midst of the gods he holds judgment: }\end{array}$ \\
\hline 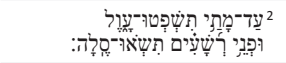 & $\begin{array}{l}2 \text { 'How long will you judge unjustly } \\
\text { and show partiality to the wicked? Selah }\end{array}$ \\
\hline 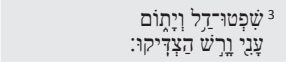 & $\begin{array}{l}{ }^{3} \text { Give justice to the weak and the orphan; } \\
\text { do justice to of the lowly and the destitute. }\end{array}$ \\
\hline 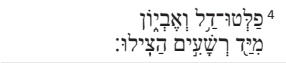 & $\begin{array}{l}{ }^{4} \text { Rescue the weak and the needy; } \\
\text { deliver them from the hand of the wicked.' }\end{array}$ \\
\hline 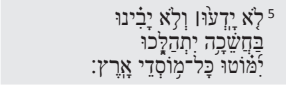 & $\begin{array}{l}{ }^{5} \text { They have neither knowledge nor understanding, } \\
\text { they walk around in darkness; } \\
\text { all the foundations of the earth are shaken. }\end{array}$ \\
\hline 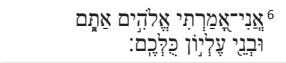 & $\begin{array}{l}{ }^{6} \text { I say, 'You are gods, } \\
\text { children of the Most High, all of you; }\end{array}$ \\
\hline 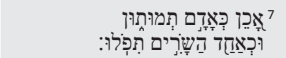 & $\begin{array}{l}{ }^{7} \text { nevertheless, you shall die like mortals, } \\
\text { and fall like any prince.' }\end{array}$ \\
\hline 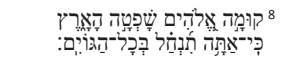 & $\begin{array}{l}{ }^{8} \text { Rise up, O God, judge the earth; } \\
\text { for all the nations belong to you! }\end{array}$ \\
\hline
\end{tabular}

14-19) portrays how Nehemiah in the post-exilic context of Yehud, acted as governor according to the ideal of the king of Psalm 72 (see below).

\section{God and the gods caring for the poor}

A third view is that the 'sons of God' (inhabiting the heavenly assembly) should have cared for the poor. This is expressed in Psalm 82 (probably to be dated in the exilic or early post-exilic period $)^{14}$ which usually receives extensive learned attention ${ }^{15}$ because of its (mythic) Near-Eastern and polytheistic background (Hossfeld \& Zenger 2002:461), with the motif of the destruction of the sons of God (movement towards monotheism), in other words the overcoming of polytheism (cf. Seybold 1996:325). In most commentaries of the first world, the motif of caring for the poor actually functions in the background. However, Psalm 82 is unique because God's rule for the benefit of the poor is expressed in polytheistic terms. ${ }^{16}$ Because of its uniqueness, it is quoted here in full (see Table 4).

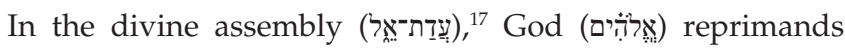

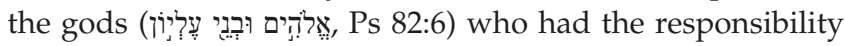
for maintaining justice (the motif also occurs in Ps 58:1) in the face of the corrupt justice that favours the godless. Emphatically expressed in a parallelismus membrorum, they

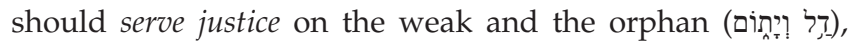

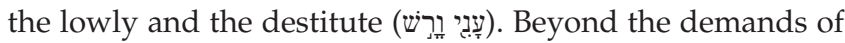

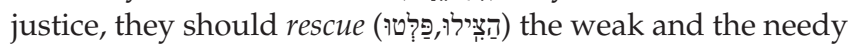

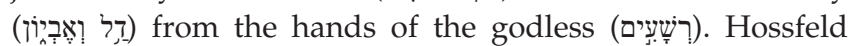
and Zenger (2002:464 identify the poor as peasants and day labourers. However, since all the standard terms for the

14.This is due to its affinity with Deutero-Isaiah and its position in the Asaph-collection (Hossfeld \& Zenger 2002:462; Seybold 1996:325).

15.See literature in Tate (1990:328) and Arneth (2007).

16.Briggs and Briggs (1907:215) and Helberg (1981:172) wrongfully (probably for reasons of faith) underplays this polytheism, interpreting the gods as the 'rulers of the nations, amongst whom Israel was scattered as a poor, weak, and afflicted people.' Interestingly, John's Jesus's use of the psalm in John 10:34 does not deny the existence of gods, thereby justifying his own position as son of God.

17.For a discussion of the 'Rat der Götter' (see e.g. 1 Kgs 22:19; Job 1-2; Ps 29:1-2, 9-10, 89:6-8; Is 6:1-3), see Kraus (1972:571). For a discussion of the Psalm as an answer to the question why the poor should suffer (the theodicy problem), see Weiser (1966:379-382). poor (and orphans) are used in the psalm, a wider range of poverty is rather implied, which includes the destitute

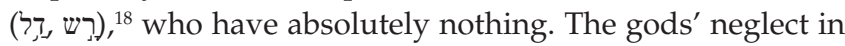
caring for the poor is so serious that it causes the 'shaking of the foundations of the earth' (Ps 82:5b). In the last verses of the psalm, it is predicted that the gods will die like men, for not doing justice (v. 7). Polytheism is thereby terminated, leaving God to rule alone over the nations since he is the 'God above the gods', and he alone meets the criterion for being a god, namely to care for the poor. Interestingly, the reason for the defeat of polytheism is not that the mere multiplicity of gods are wrong but that these gods failed to care for the poor, thus leaving Elohim or Elyon as the only just and merciful God that take the plight of the poor to heart. This dramatic psalm communicates how important caring for the poor is: If it is not done, it has catastrophic cosmic consequences; it can even break up a pantheon.

\section{Caring for the poor in terms of (idealistic) Zion theology}

A fourth view is that a descendant of the Davidic dynasty will care for the poor. In Psalm 132:15 (dated to shortly after the exile, Prinsloo 2003:428), ${ }^{19}$ the needs of the poor are addressed in terms of Zion theology. As in bygone times, YHWH will again rule there through a descendant of David (Ps 132:11, 14), because of the latter's virtuous behaviour in the past (132:1-10). According to verse 15, his rule consists, amongst others, of the fact that he will abundantly bless her

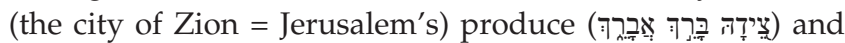

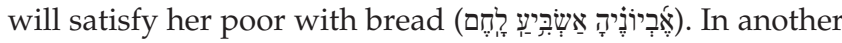
'psalm of Zion' (Ps 76:3), Elohim who dwells in Zion (v. 3) will surprisingly 'save the poor of the earth' (v. 10), and not

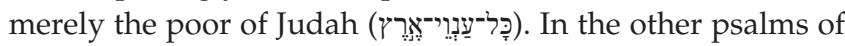
Zion (Pss 46, 48, 84, 87, 89 and 122), the motif of caring for the poor is absent, indicating that it was not a dominant motif in Zion theology which focused more on the indestructability of Jerusalem. ${ }^{20}$ In terms of Maslow's theory (cf. above), both lower and higher-order needs will therefore be satisfied in this theology. In Psalm 132, the joy of the faithful in verse $16 \mathrm{~b}$ and David's high standing in verses 17-18 can be interpreted as higher needs. Here one clearly sees that, although other spiritual and nationalistic needs are given due attention in terms of Zion theology, the basic need for food (avoiding extreme or killing poverty) is at least still addressed.

\section{God (YWHW) as unjust crusher of the poor}

Interesting (and often avoided by pious Bible readers) is the idea also expressed in some psalms that God (who generally functions as the saviour of the poor) is also interpreted as the unjust crusher of the pious poor. The standard terms are not mentioned in the psalm, but (affliction, poverty, suffering)

18.Used only here in Psalms.

19.Anderson (1962:441) dates the psalm (to my mind wrongfully) to the monarchic period.

20.Other motifs linked to Davidic messianic rule in the psalm are the joy of the priests, the permanency of the Davidic dynasty and the humiliation of the enemy (Prinsloo 2003:428) 
is used in verse 10 and in vָנִינ in verse 16 of Psalm 88 ('my eyes are grow dim through sorrow'). In Psalm 88, there is no positive outcome, and the cause of the petitioner's suffering is not attributed to the enemy but to God: The petitioner accuses YHWH of crushing him by his anger (Ps 88:7, 15) and destroying him by his terrible attacks (Ps 88:16-19). In Psalm 51:8, reference is made to the 'bones which thou hast broken', and the famous Psalm 22:1 exclaims: 'My God, my God, why has thou forsaken me?' In Psalm 78:31-35 and 6164, the crushing by God ('making their days vanishing like a breath', 'giving his people over to the sword') functions as punishment for Israel. In Psalm 89:38-45, YHWH even 'casts down the throne' of his anointed. In Psalm 90:7-9, the (mortal) petitioner is 'consumed' by God's anger. Psalm 102 oscillates between YHWH's indignation and anger

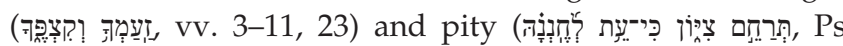
102:13-14), indicative of humankind's endeavour to explain its suffering as coming from God but simultaneously calling on God to relieve it.

\section{Ordinary people caring for the poor or mutual charity amongst the poor}

A sixth view is that ordinary people should care for the poor or that there should be mutual charity amongst the poor. References where ordinary people are encouraged to care for the poor are not a characteristic feature of the psalms (cf. contra Prov $14: 21 ; 19: 17 ; 22: 9)$ though not totally absent. In

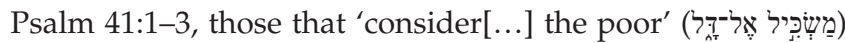

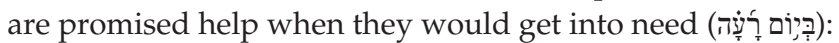

Happy are those who consider the poor; YHWH delivers them in the day of trouble.

${ }^{2}$ YHWH protects them and keeps them alive; they are called happy in the land.

You do not give them up to the will of their enemies.

${ }^{3}$ YHWH sustains them on their sickbed; in their illness you heal all their infirmities.

In Psalm 112, the good person who fears YHWH 'takes pity and lends' (v. 5), 'open-handed he gives to the poor' (v. 9). He

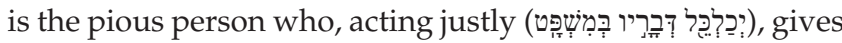

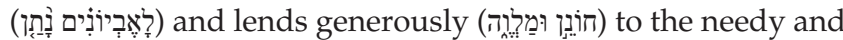
is praised and honoured, 'his head will be raised in glory' (v. 9). In the lament for the temple of Psalm 74, the care for the poor is expressed in the fact that the petitioner prays for them: 'do not forget the life of your poor forever ... Do not let the downtrodden be put to shame; let the poor and needy praise your name (vv. 19, 21).

\section{Poor piety: ${ }^{21}$ The petitioner(s) as the spiritually poor (Armenfrömmigkeit), or 'pleading poverty'?}

The seventh view on poverty, to my mind unique to the psalms, demands our cautious attention. In the psalms, the supplicant on numerous occasions designates him or herself

21.In view of the possible deception in this piety, there is a certain pun intended in the choice of words. For an elaborate discussion, see Scheffler (2011a). as poor in view of the dangerous threat of the enemy. In such cases, the petitioner is not necessarily materially poor but identifies with the poor to receive God's rescue and help which the latter usually gives to the poor. In Psalm 70 (repeated in Ps 40:13-17), the petitioner prays that God will disgrace his enemies. He himself is wretched and poor

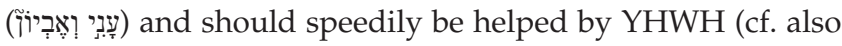
Pss $9 ; 18 ; 22 ; 25 ; 35 ; 41 ; 68 ; 70 ; 74 ; 86 ; 102 ; 109: 16)$.

In Psalm 109, this motif of being at odds with the enemy is acutely expressed when the petitioner refers to himself as 'poor and needy' especially in terms of extreme poverty.

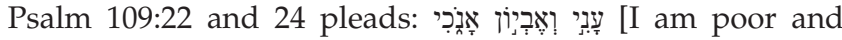

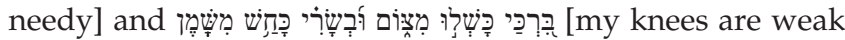
from lack of food, I get thin because of \{a lack of $\}$ oil]. The petitioner's hatred for the enemy is vengefully expressed in terms of the enemies whom God should crush into poverty: The enemy's children should become orphans, homeless beggars. The enemies must lose all their property, their offspring should die, and because of their persecution of the poor, they should perish without blessings and be cursed (as such Ps 109:6-19 is a vivid description of poverty in all its dimensions). God's championing for the needs of the poor in this psalm seems clearly to be expressed only in inclusive terms (self-interest, cf. Scheffler 2011a). The enemy should become extremely poor until death.

Some scholars argue that the notion of spiritualising or theologising the poor (Armenfrommigkeit) occurs in the psalms (cf. the cases where the petitioners refers to themselves as ani weebyon). Even so, this fact does not neutralise the basic economic meaning of the terms for poverty, and this 'piety of the poor' is also not to be judged positively. It rather constitutes 'poor piety'. It represents the metaphorical use of the terms in view of other possible higher-order needs that crave fulfilment (e.g. security in terms of the enemy, success in society and probably also the need for self-fulfilment). The Armenfrömmigkeit that developed amongst relatively well-off people can perhaps be understood in terms of the latter.

When we therefore read psalms where the petitioner refers to themselves as poor, we should be on the alert. Is the plight of the desperate poor (on whose side God surely is, as expressed in the rest of the psalms) the ultimate concern? The reader of the psalm is most probably manipulated by relative affluent authors, who regard themselves as disadvantaged for whatever reason, pleading poverty for selfish reasons. Furthermore, if we as the non-poor spiritualise the concept of poverty so that we can identify with the poor in the psalms whilst overlooking the plight of the really destitute, we do the same.22

\section{Preliminary conclusion}

Is it at all possible to listen to voices of the ancient past, especially with regard to the problem of poverty, and if so,

22. Hossfeld and Zenger (2008:195) discusses the misuse of this psalm in the Christian context but - to my mind wrongfully - attempts to justify the perspective expressed in it, calling it not a 'Fluchpsalm' but a 'Gerechtigkeitspsalm' 
how do we do it? In what follows, I want to address the issue of what to do with these voices if we have indeed heard them or at least think that we have heard them.

The Pentateuch contains definite measures to combat poverty (Scheffler 2013b). These measures cannot be applied in the same form to today's contexts. (Sabbath and Jubilee Years can even be economically unproductive in today's world.) However, studying poverty in the Pentateuch and the Psalms reminds us that theologising and reflecting on the poor in an armchair fashion is not enough. Proper action stands in need to be taken, suitable and in accordance with the demands in various contexts (whether these be African or Asian, or even unnoticed instances of extreme poverty in the first world). As such, the views expressed in the Pentateuch serve as a corrective on views often expressed in the Psalms where the concept of the poor is sometimes spiritualised or theologised. In these views of the psalms, the familiar positive involvement of God with the fate of the poor is employed by the petitioner in terms of his or her own plight which is indeed related to possible higher-order human needs but not to material poverty as such.

An 'intra-biblical' example of the positive application of the sentiments of the psalms (beneficial to the real poor) can be found in Nehemiah 5 (especially vv. 14-19), which portrays how Nehemiah in the post-exilic context of Yehud acted as governor according to the ideal of the caring king of Psalm 72. Its significance for our current South African situation demands it to be quoted:

${ }^{14}$ Neither I nor my kinsmen ever ate governor's bread. ${ }^{15}$ The former governors who were before me laid heavy burdens on the people, and took food and wine from them, besides forty shekels of silver. Even their servants oppressed the people. But I did not do so, because of the fear of God $\ldots{ }^{17}$ Moreover there were at my table one hundred and fifty people, Jews and officials, besides those who came to us from the nations around us. ${ }^{18}$ Now that which was prepared for one day was one ox and six choice sheep; also fowls were prepared for me, and every ten days skins of wine in abundance; yet with all this I did not demand the food allowance of the governor, because of the heavy burden of labour on the people. (Neh 5:14-19)

Looking for present-day answers for the alleviation for poverty ${ }^{23}$ also calls for exposing the 'hate-language' which one often encounters in the psalms, without losing empathy for people's existential experiences in ancient times. The book of the psalms may, form a certain perspective, be regarded as 'the prayer book of the poor', but if attitudes that are expressed there are not filtered through the concepts of brotherly and sisterly love and even love for the enemy, there is no hope that the plight of the extreme poor could be eradicated or even ameliorated.

This filtering process happens in the popular psalms commentary of Da Silva et al. (1999). At one point in the

23.For a different kind of (and to my mind meaningful in its own right) appropriation of the poverty concept of the psalms in our (post)modern world, see Adamo (2014:797815) who compares the psalms with the Yoruba tradition. commentary, the authors made the to my mind frail attempt to justify the hatred towards the enemy which we encounter in the psalms. Commenting on the psalms that curse the enemy, they write (Da Silva et al. 1999):

These psalms are not about unqualified hate or revenge against the enemy, but about removing that which causes disharmony in God's good creation. Further we must note that these psalms advocate first of all the honour of God. And when his honour is affected, his children have to react. (p. 630)

However, and fortunately, commenting on Psalm 109, perhaps the most prominent cursing psalm, where the petitioner describes himself as poor and needy and then proceeds to wish the severest poverty to his enemy, the authors of the commentary conclude the following (Da Silva et al. 1999):

The author still lived in a time of the law which says, an eye for an eye and tooth for a tooth ... But that time is past. From the time which Christ on the cross asked forgiveness for the people that killed him, everything changed. From that day God wants his honour to be defended in a new manner, namely by loving your enemy (Mt 5:43), by doing to others that you want to have done to yourself, to respond to hatred with goodness and to forgive endlessly. (p. 681)

To these sentiments I can fully ascribe - despite failing every day to put them into practice. The Psalms' positive views on poverty should be appropriated, but where it is expressed in a context of enmity, the sentiments emanating from that hostile context should - in view of the clear teaching of Jesus of Nazareth - be surpassed.

Although poverty (material destitution) is generally negatively regarded in the Hebrew Bible, various views on how poverty can be alleviated do exist in the Bible. In the Pentateuch (especially Dt 15:1-11), society is regarded as a family, and the emphasis is on measures and rules that should exist in the community to minimise and even eradicate poverty. The psalms (which generally functioned in a liturgical context, e.g. Pss. 9, 72, 82, 132) have a more 'religious, existential approach'. God is viewed and called upon as the champion of the poor and interacts on their behalf. These psalms had a critical function in an ancient Israelite society where wealth and success were positively valued as a 'blessing' of God (e.g. Abraham and Solomon). The various perspectives on poverty detected in the Psalms (although different) are relevant in a (post)modern world where poverty is still rife and where capitalistic values are not sufficiently tamed by the profound human value of caring for the poor (compassion). Despite the fact that we can detect a misuse of the concept of poverty in some psalms, God's compassion for the poor and human compassion (whether it be from the king or ordinary people) are prominently and strongly advocated. We are obliged to sing about it from our hymn books, and such singing should hopefully motivate us into action. 


\section{Acknowledgements}

\section{Competing interests}

The author declares that he has no financial or personal relationships which may have inappropriately influenced him in writing this article.

\section{References}

Adamo, D.T., 2014, 'The poor in the book of psalms and in the Yoruba tradition', Old Testament Essays 27(3), 797-815.

Anderson, G.W., 1962, 'Psalms', in M. Black \& H.H. Rowley (eds.), Peake's commentary on the Bible, pp. 409-444, Thomas Nelson, Nairobi.

Arneth, M., 2007, 'Erkenntnis Gottes und des Menschen nach Psalm 82 und Genesis 3', Zeitschrift für Altorientalische und Biblische Rechtsgeschichte 13 304-218.

Briggs, C.A. \& Briggs, E.G., 1907, A critical and exegetical commentary on the book of the Psalms, T \& T Clarke, Edinburgh.

Cloete, T.T., 2001, 'Psalm 146', Liedboek van die kerk vir gebruik by die erediens en ander byeenkomste, NG Kerk-Uitgewers, Kaapstad.

Da Silva, A.A., Human, D.J., Prinsloo, G.T.M., Botha, P.J. \& Potgieter, J.H., 1999, 'Psalms' in W. Vosloo \& F.I.J. van Rensburg (eds.), Die Bybellennium: Die Bybel uitgelê vir eietydse toepassing, pp. 600-607, Christelike Uitgewersmaatskappy, Vereeniging.

Deist, F., 1987, 'Israel in ' $n$ tyd van verandering: 900-800 vC', in F.E. Deist \& J.H. le Roux (eds.), Rewolusie en reïnterpretasie: Hoofstukke uit die geskiedenis van Israel, pp. 46-100, Tafelberg, Kaapstad.

Groenewald, A. 2003, Psalm 69: Its structure, redaction and composition, Lit Verlag, Munster.

Gunkel, H., 1933, Einleitung in die Psalmen, Vandenhoeck \& Ruprecht, Göttingen.

Helberg, J., 1981, Loof die Here: Die Psalms in Ou- en Nuwe-Testamentiese lig, NG Kerkboekhandel, Pretoria.

Hjelle, L.A. \& Ziegler, D.J., 1976, Personality theories: Basic assumptions, research, and applications, McGraw Hill, New York.

Hossfeld, F-L. \& Zenger, E., 2002, Die Psalmen II: Psalm 51-100, Echter Verlag, Würzburg.

Hossfeld, F-L. \& Zenger, E., 2008, Psalmen 101-150: Übersetzt und ausgelegt, Herder, Freiburg.
Houston, W., 1999, 'The king's preferential option for the poor: Rhetoric, ideology and ethics in Psalm 72', Biblical Interpretation 7(4), 341-367. http://dx.doi. org/10.1163/156851599X00272

Köhler, L. \& Baumgartner, W., 1958, Lexicon in veteris testamenti libros, Brill, Leiden.

Kraus, H.J., 1972, Psalmen. 2. Teilband: Psalmen 64-150, Neukirchener Verlag, Neukirchen.

Kraus, H.J., 1979, Theologie der Psalmen, Neukirchener Verlag, Neukircken.

Lohfink, L., 1994, Die Armen in den Psalmen. Teil 1 \& II, Hochschule Sankt Georgen, Frankfurt am Main. (Vorlesungsmanuskript Wintersemester 1992-1994).

Maslow, A., 1970, Motivation and personality, Harper \& Row, New York.

Prinsloo, W.S., 2003, 'The Psalms', in J.D. Dunn \& J.W. Rogerson (eds.), Eerdmans Commentary on the Bible, pp. 346-436. W.B. Eerdmans, Grand Rapids.

Sachs, J., 2005a, The end of poverty: How we can make it happen in our life time, Penguin, London.

Sachs, J., 2005b, 'The end of poverty', Time 165(11), 26-36.

Scheepers, C., 2012, 'Survival strategies in ancient Israel: An archaeological perspective', in E.H. Scheffler \& W. van Heerden (eds.), The Bible and the eradication of poverty: Study guide 1 for OTS2604, pp. 23-41, UNISA, Pretoria.

Scheffler, E.H., 2005, 'Deuteronomy 15:1-18 and poverty in (South) Africa', in J.H. le Roux \& E. Otto, (eds.), A critical study of the Pentateuch, pp. 97-115, Lit Verlag, Munster.

Scheffler, E.H., 2007, 'Criticism of government: Deuteronomy 17:14-20 between (and beyond) synchrony and diachrony', in J.H. le Roux \& E. Otto (eds.), South African perspectives on the Pentateuch between synchrony and diachrony, pp. 124-137, T \& T Clarke, Edinburgh. (Also published in Old Testament Essays 20(3), 772-785.

Scheffler, E.H., 2011a, 'Pleading poverty (Or: Identifying with the poor for selfish reasons): On the ideology of Psalm 109', Old Testament Essays 24 (1), 192-207.

Scheffler, E.H., 2011b, 'Luke's view on poverty in its ancient (Roman) economic context: A challenge for today', Scriptura 106, 115-135. http://dx.doi.org/10.7833/106-0152

Scheffler, E.H., 2012, 'Poverty in the book of Proverbs: Looking from above?', Scriptura 111, 480-496. http://dx.doi.org/10.7833/111-1-30

Scheffler, E.H., 2013a, 'Poverty eradication and the Bible in context: A serious challenge', Studia Historiae Ecclesiasticae 24, 129-153.

Scheffler, E.H., 2013b, 'Of poverty prevention in the Pentateuch as a continuing contemporary challenge', Verbum et Ecclesia 34(2), Art. \#869, 14 pages. http:// dx.doi.org/10.4102/ve.v34i2.869

Seybold, K., 1996, Die Psalmen, Mohr, Tübingen. (Herder's Kommentar zum Alten Testament I/15)

Tate, M.E., 1990, Psalms 50-100, Word Books, Dallas.

Weiser, A., 1966, Die Psalmen, 7th edn., Vandenhoeck \& Ruprecht, Göttingen. 